\title{
Blood lead level among Palestinian schoolchildren: a pilot study
}

\author{
A.F. Sawalha, ${ }^{1}$ R.O. Wright, ${ }^{2}$ D.C. Bellinger, ${ }^{2}$ C. Amarasiriwardean, ${ }^{2}$ A.S. Abu-Taha ${ }^{3}$ and W.M. Sweileh ${ }^{3}$
}

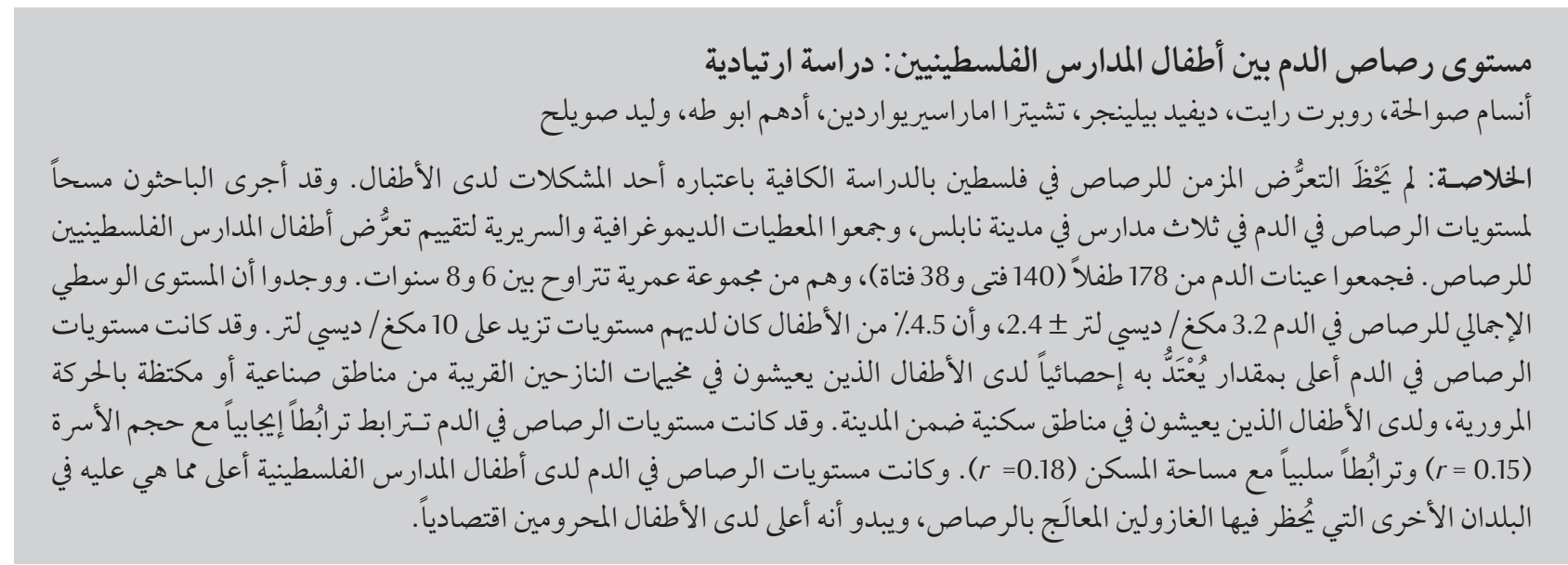

ABSTRACT In Palestine, chronic exposure to lead has not been adequately addressed as a problem for children. To assess the exposure of Palestinian schoolchildren, we surveyed blood lead levels in 3 schools in Nablus city and collected demographic and clinical data. Blood samples were collected from 178 children (140 boys, 38 girls), age range 6-8 years. The overall mean blood lead level was 3.2 (SD 2.4) $\mu \mathrm{g} / \mathrm{dL}$, and $4.5 \%$ of children had levels above $10 \mu \mathrm{g} / \mathrm{dL}$. Blood lead levels were significantly higher among children living in refugee camps near industrial/high traffic regions than among children living in residential areas of the city. Blood lead levels were positively correlated with family size $(r=0.15)$ and negatively correlated with household area $(r=-0.18)$. Blood lead levels among these Palestinian schoolchildren were higher than those of other countries where leaded gasoline has been banned and seemed to be higher in more economically deprived children.

\section{Concentration sanguine de plomb chez des écoliers palestiniens : une étude pilote}

RÉSUMÉ En Palestine, l'exposition chronique au plomb n'a pas été abordée adéquatement comme un problème chez l'enfant. Pour évaluer l'exposition des écoliers palestiniens, nous avons recherché les taux de plomb sanguins chez des élèves de trois écoles de la ville de Naplouse et avons recueilli les données démographiques et cliniques. Des échantillons de sang ont été recueillis auprès de 178 enfants (140 garçons, 38 filles), âgés de six à huit ans. La concentration de plomb moyenne globale dans le sang était de 3,2 $\mu \mathrm{g} / \mathrm{dl}$ (E.T. 2,4), et 4,5\% des enfants présentaient des niveaux supérieurs à $10 \mu \mathrm{g} / \mathrm{dl}$. Les taux de plomb sanguins étaient nettement plus élevés chez les enfants vivant dans des camps de réfugiés près de zones industrielles/de circulation intense que chez les enfants vivant dans des zones résidentielles de la ville. Les taux de plomb dans le sang étaient positivement corrélés à la taille de la famille $(r=0,15)$ et négativement corrélés au nombre de mètres carrés du logement familial $(r=-0,18)$. Les taux de plomb dans le sang chez ces écoliers palestiniens étaient supérieurs à ceux d'autres pays où le carburant contenant plomb a été interdit. Ils semblaient aussi supérieurs chez les enfants plus faibles économiquement.

${ }^{7}$ Poison Control and Drug Information Centre; ${ }^{3}$ College of Pharmacy, An-Najah National University, Nablus, Palestine (Correspondence to A.F. Sawalha: ansam@najah.ed).

${ }^{2}$ Harvard Medical School and School of Public Health, Boston, Massachusetts, United States of America.

Received: 22/11/11; accepted: 05/02/12 


\section{Introduction}

Lead is a toxic heavy metal that is ubiquitous in the environment as a result of industrialization. Exposure occurs primarily through ingestion and inhalation [1,2]. In the Middle East, the major reported sources of lead exposure are industrial, including smelters, battery factories and radiator repair shops; flour from traditional stone mills; and the occasional burning of wastes $[3,4]$. In Palestine, leaded gasoline used by automobiles remains the major source of environmental lead pollution. These exposures can be prevented by increasing public health awareness and by implementing measures to phase out sources of lead from the environment.

Lead poisoning frequently goes unrecognized. Elevated blood lead levels (BLL) can adversely affect many organ systems including mental development [5], haemoglobin level [6], kidney function [7], cardiovascular function in adults and reproduction in women [8]. It has been reported that even slightly elevated levels can result in reduced IQ, learning disabilities and behavioural problems $[9,10]$. The United States Centers for Disease Control and Prevention (CDC) recommends a BLL of $10 \mu \mathrm{g} / \mathrm{dL}$ or above as the level of concern at which public health action needs to be initiated. The CDC consider low-dose exposure to lead poisoning in children to be a preventable paediatric health problem and have emphasized the need for primary prevention [11]. Therefore screening for elevated BLL and prevention measures are recommended [11], including universal screening, if the prevalence of elevated BLL in the community is unknown.

In Palestine, chronic exposure to lead has not been adequately addressed as a problem for schoolchildren of different socioeconomic strata. Health care providers do not routinely screen children for lead exposure, and so no data are available to evaluate BLL and the extent of lead exposure in schoolchildren.
Furthermore, baseline data about BLL in children are important to inform advocacy efforts to phase out leaded gasoline in Palestine. Such data need to take into consideration the social and economic differences between children living in different environments. This study therefore aimed to investigate BLL among schoolchildren in Palestine, with emphasis on the comparison between those living in a refugee camp environment and those living in the city.

\section{Methods}

\section{Study settings and schools}

This cross-sectional survey was carried out in the spring of 2009 in Nablus city, one of the largest cities in the West Bank of Palestine. The total population of the West Bank is approximately 2.5 million, $20 \%$ of whom have been living in refugee camps since 1948 [12].

The sample was taken from among 1000 first-grade students attending 3 schools in different areas of Nablus. The schools were selected to represent different geographic and socioeconomic strata in the city. We choose 2 of the 3 refugee camp schools run by the United Nations Relief and Works Agency for Palestine Refugees in the Near East (UNRWA). The choice of UNRWA schools was based on the fact that the populations of refugee camps are characterized by low socioeconomic status and poor health standards. The camps have concrete houses built before 1950, with narrow streets and high population density and are located close to the main streets with heavy traffic which might to greater lead exposure for children. Al-Ain UNRWA school is located at the northern part of Nablus city and serves boys living at Al-Ain refugee camp. Asker UNRWA school is located in the eastern part of Nablus city, close to an industrial area, and serves solely boys, who have a similar background to children who attend Al-Ain UNRWA school. We also chose 1 of the estimated 10 private schools, which was located at the middle of Nablus city away from the main highway and which therefore might have lower exposure to environmental lead. Private schools are attended by children from families living outside the refugee camps, who generally have higher economic and parental education levels. The Al-Talaa private school has approximately 1000 students who come from a number of different residential areas in Nablus city.

\section{Sample}

We calculated the sample size with a 99\% confidence limit with an interval of \pm 2 and a standard deviation of 5 . The expected sample size was 166 . The final sample included 103 first graders from around 300 in total at the UNRWA schools and 75 first graders from around 150 at the private school, which represented approximately $45 \%$ of children who were invited to participate in the study and 6\% (178/3000) of the total number of 6-8-year-old children in Nablus city.

\section{Data collection}

On the first day of the study, all children in the 3 selected schools were given a written consent form and a brochure explaining the study to be handed to their parents. Of 400 consent forms distributed, 178 were signed by the parents and returned to the researchers a week later.

Before venous blood samples were collected, parents completed a questionnaire to collect data about sociodemographic parameters, child's general health status (i.e. presence of any eating or sleeping problems, growth problems, any diseases suffered, vaccinations taken and potential sources of lead exposure in the home environment). The questionnaire was written in Arabic. The questionnaires were filled by parents without assistance from the authors. Only children who brought back the completely filled questionnaire along with a signed consent form were included in the study. 
For each child, weight, height and arm circumference were measured before blood sample collection. Blood sample collection was carried out by well trained nursing staff supervised by a medical laboratory expert.

Blood samples were analysed for lead at the trace metals laboratory at Harvard School of Public Health in Boston, Massachusetts. For the lead assay blood samples were first weighed $(\sim 1 \mathrm{~g})$ and digested for 24 hours in 2 $\mathrm{mL}$ of concentrated nitric acid. These samples were then treated with $1 \mathrm{~mL}$ of $30 \%$ hydrogen peroxide per $1 \mathrm{~g}$ of blood and left overnight. Samples were subsequently diluted to $10 \mathrm{~mL}$ with deionized water. Lead concentrations were measured using a dynamic reaction cell-inductively coupled plasma mass spectrometer (DRC-ICP-MS, DRC II, Perkin Elmer). Analyses were performed using an external calibration method, with lutetium as the internal standard for lead.

Quality control measures included analysis of initial and continuous calibration verification standards [National Institute of Standards and Technology standard reference material for trace elements in water (NIST 1643e)], 1 ppb lead standard, procedural blanks, duplicate samples, spiked samples and certified reference material (NIST 955b in bovine blood for lead) to monitor for contamination, accuracy and recovery rates. Recovery rates for lead in quality control and spiked samples were $90 \%-$ $115 \%$, and precision was measured as $\%$ relative standard deviation (SD) and it was less than $5 \%$ for lead. The limits of detection of lead were $0.2 \mu \mathrm{g} / \mathrm{dL}$. Results from ICP-MS analyses are the average of 5 replicate measurements.

\section{Data analysis}

Data obtained from questionnaires and blood sample analyses were analysed using SPSS, version 16 for Windows. Comparisons among the 3 schools were made using robust ANOVA test with Tukey post hoc analysis. Correlations between continuous variables were assessed using Pearson correlation. The significance level was set at $P<0.05$.

\section{Results}

\section{Background demographic and clinical data}

A total of 178 children were included in the study ( 75 from Al-Tala private school, 31 from Al-Ain UNRWA school and 72 from Asker UNRWA school). In our sample, there were 140 boys (78.7\%) and 38 (21.3\%) girls; all the girls were from Al-Talaa private school. The mean age of the children was 6.4 (SD 0.5) years, range 6-8, median 6 years.

The mean family size, measured as number of family members, was 4.3 (SD 1.7) and the mean household area was $126(\mathrm{SD} 66) \mathrm{m}^{2}$. There was a significant difference among children in the 3 schools with regard to family size. Children at Al-Talaa private school had the smallest family size [3.6 (SD 1.4)] and Al-Ain UNRWA school had the highest [5.2 (SD 1.9)] (Table 1). There was also a significant difference among children in the 3 schools with regard to household area, with children at AlTalaa having the largest household area 152 (SD 45) $\mathrm{m}^{2}$ and Al-Ain UNRWA school the lowest [104 (SD 75) $\mathrm{m}^{2}$ ] (Table 1).

Their mean haemoglobin level of the children was 12.3 (SD 0.8) g/dL. The mean weight of the children was 23.5 (SD 3.9) kg, and the mean arm circumference was 17.5 (SD 1.7) cm. For Al-Ain UNRWA school, the mean weight was 23.3 (SD5.7) kg, for AlTalaa it was 24.1 (SD 3.5), kg and for Asker it was 22.9 (SD 3.1) kg. As for the arm circumference, it was 17.2 (SD 2.4) $\mathrm{cm}$ for Al-Ain, 17.9 (SD 1.5) cm for AlTalaa and 17.2 (SD 1.3) cm for Asker.

\section{Blood lead levels}

The mean BLL among all children when the 3 sites were pooled was 3.2
(SD 2.4) $\mu \mathrm{g} / \mathrm{dL}$. However, 8 children (4.5\%) had BLL above $10 \mu \mathrm{g} / \mathrm{dL}$ (maximum was $13.9 \mu \mathrm{g} / \mathrm{dL}$ ), which is the level of concern according to CDC guidelines. All 8 children with a BLL > $10 \mu \mathrm{g} / \mathrm{dL}$ were from Asker UNRWA school. Further analysis showed that there were significant differences in BLL among children from the 3 schools $(P<$ $0.01, F=41)$. The lowest mean blood lead levels were at the private school $[1.9(\mathrm{SD} 0.6) \mu \mathrm{g} / \mathrm{dL}$, range $0.7-4.3$ $\mu \mathrm{g} / \mathrm{dL}]$, followed by Al-Ain UNRWA school [2.7 (SD 0.9), range 1.2-4.4 $\mu \mathrm{g} / \mathrm{dL}]$, while Asker UNRWA school had the highest level [4.9 (SD 0.4) $\mu \mathrm{g} /$ $\mathrm{dL}$, range $0.8-13.9 \mu \mathrm{g} / \mathrm{dL}]$. Post hoc analysis using the Tukey test showed that children at Asker UNRWA school had a significantly higher mean BLL than children at Al-Tala private school $(P<0.01)$ or at Al-Ain UNRWA school $(P<0.01)$.

\section{Risk factors for high lead levels}

Pearson correlation analysis showed that age was not correlated with BLL for the whole sample or at any of the 3 schools $(P>0.5)$. The only school with data on both boys and girls was Al-Talaa private school. The mean BLL for boys at was $2.0(\mathrm{SD} 0.7) \mu \mathrm{g} / \mathrm{dL}$ and for girls at the same school was 1.9 (SD 0.6) $\mu \mathrm{g} /$ dL. This difference was not statistically significant $(P>0.05)$.

None of the other health parameters measured (haemoglobin level, weight or arm circumference) were significantly correlated with BLL. Family size was positively correlated with children's BLL $(r=0.153, P=0.048)$ and household size was negatively correlated with BLL $(r=-0.18, P=0.031)$ (Table 1).

\section{Discussion}

Lead is considered a serious neurotoxicant, and research suggests that children's intellectual functioning is impaired by BLL concentrations even 


\begin{tabular}{|c|c|c|c|c|c|c|c|}
\hline \multirow[t]{2}{*}{ Variable } & \multicolumn{2}{|c|}{$\begin{array}{l}\text { Al-Talaa private school } \\
\qquad(n=75)\end{array}$} & \multicolumn{2}{|c|}{$\begin{array}{l}\text { Al-Ain UNRWA school } \\
\qquad(n=31)\end{array}$} & \multicolumn{2}{|c|}{$\begin{array}{l}\text { Asker UNRWA school } \\
\qquad(n=72)\end{array}$} & \multirow[t]{2}{*}{$P$-value } \\
\hline & No. & $\%$ & No. & $\%$ & No. & $\%$ & \\
\hline \multicolumn{8}{|l|}{ Sex } \\
\hline Male & 37 & 49 & 31 & 100 & 72 & 100 & \\
\hline \multirow[t]{2}{*}{ Female } & 38 & 51 & 0 & 0 & 0 & 0 & \\
\hline & \multicolumn{2}{|c|}{ Mean (SD) } & \multicolumn{2}{|c|}{ Mean (SD) } & \multicolumn{2}{|c|}{ Mean (SD) } & \\
\hline Age (years) & \multicolumn{2}{|c|}{$6.4(0.5)$} & \multicolumn{2}{|c|}{$6.4(0.7)$} & \multicolumn{2}{|c|}{$6.5(0.5)$} & \\
\hline Family members (no.) & \multicolumn{2}{|c|}{$3.6(1.4)$} & \multicolumn{2}{|c|}{$5.2(1.9)$} & \multicolumn{2}{|c|}{$4.4(1.7)$} & $<0.01$ \\
\hline Household area $\left(\mathrm{m}^{2}\right)$ & \multicolumn{2}{|c|}{$152(45.0)$} & \multicolumn{2}{|c|}{$104(75)$} & \multicolumn{2}{|c|}{$105(73)$} & $<0.01$ \\
\hline Arm circumference $(\mathrm{cm})$ & \multicolumn{2}{|c|}{$17.9(3.5)$} & \multicolumn{2}{|c|}{$17.2(2.4)$} & \multicolumn{2}{|c|}{$17.2(1.3)$} & NS \\
\hline Weight (kg) & \multicolumn{2}{|c|}{$24.1(3.5)$} & \multicolumn{2}{|c|}{$23.3(5.7)$} & \multicolumn{2}{|c|}{$22.9(3.1)$} & NS \\
\hline Haemoglobin level (mg/dL) & \multicolumn{2}{|c|}{$12.3(0.7)$} & \multicolumn{2}{|c|}{$12.2(0.9)$} & \multicolumn{2}{|c|}{$12.5(0.8)$} & NS \\
\hline Blood lead level ( $\mu \mathrm{g} / \mathrm{dL})$ & \multicolumn{2}{|c|}{$1.9(0.6)$} & \multicolumn{2}{|c|}{$2.7(0.9)$} & \multicolumn{2}{|c|}{$4.9(0.4)$} & $<0.01$ \\
\hline
\end{tabular}

UNRWA = United Nations Relief and Works Agency for Palestine Refugees in the Near East; SD = standard deviation; NS=not significant.

below $10 \mu \mathrm{g} / \mathrm{dL}[9,10]$. This suggests that BLL in children should be reduced as much as possible [13]. In our study, the mean BLL among school-age children was 3.2 (SD 2.4) $\mu \mathrm{g} / \mathrm{dL}$. This is higher than that the average level found in US schoolchildren $(1.9 \mu \mathrm{g} / \mathrm{dL})$ [14-16]. The mean BLL of children 6-11 years of age in the US was $1.9 \mu \mathrm{g} /$ $\mathrm{dL}$ in the early 1990s and the rate of BLL $>10 \mu \mathrm{g} / \mathrm{dL}$ was $2.0 \%$ in the early 1990s and is continuing to drop [16]. It is encouraging that the mean level was not even higher, considering the harsh economic situation, environmental pollution and the continued use of leaded gasoline in Palestine.

Our results are similar to those reported in a previous study in Palestine by Safi et al. who reported that the mean BLL in Palestinian pre-school children (2-6 years of age) was 4.2 $\mu \mathrm{g} / \mathrm{dL}$ and $5.2 \%$ had BLL $>10 \mu \mathrm{g} / \mathrm{dL}$ [17]. In the same study, the mean BLL among pre-school children in Jordan and Israel was found to be $3.2 \mu \mathrm{g} / \mathrm{dL}$. The children in our sample were older (6-8 years) than Safi et al.'s sample and it might be expected that BLL for children in our study would be higher due to increased exposure to sources of lead over time. Younger children, however, typically have higher BLL than school-age children due to their hand-to-mouth behaviours and 2-4 years of age are the peak ages for lead poisoning [5]. Age as a risk factor for elevated BLL among children 4-12 years of age has not generally been reported. In a study in Russia, little variation in BLL by age was found [18]. Studies from the United States and Australia showed that BLL were highest in 1-2-year-old children and declined at older ages $[19,20]$.

In our study, the mean BLL were highest among the children living in a refugee camp near an industrial area with high traffic and lowest among children living in residential areas away from high traffic. A study carried out in Cairo, Egypt among children 3-15 years of age found that the mean BLL was $4.82(\mathrm{SD} 2.97) \mu \mathrm{g} / \mathrm{dL}$ with a range $1.1-14.3 \mu \mathrm{g} / \mathrm{dL}$, and that children living in high traffic areas had the highest mean levels [21]. The mean BLL in our study was lower than levels reported from countries in which leaded gasoline is still used $[22,23]$. At the time of this study, leaded gasoline was still sold at gasoline stations in Palestine. In countries that plan to phase out leaded gasoline, baseline BLL is critical to develop and evaluate intervention policies [24]. International experience shows that it might take years to see substantial reductions in lead levels in the environment after lead is removed from gasoline [24].

Our study had a number of limitations. First, the surveyed schools were not randomly selected and recruitment of children within schools depended on attendance and parental consent. However, the selected schools represented a spectrum of geographic and socioeconomic strata, and the true mean geographic BLL levels of first-grade children was likely to be within the range found. Our sample size may not have allowed detection of small statistical associations between some potentially important exposure sources and elevated BLL levels. Finally, there was a biased distribution of the sexes from the different schools because in the UNRWA schools, only males students agreed to participate, whereas in the private school, both males and females participated. However, since our study was a pilot and exploratory study, this limitation can be overcome in the later studies to be carried out at the national level. 


\section{Conclusions}

Our study examined BLL among firstgrade schoolchildren living in different parts of Nablus city, West Bank, Palestine. The major findings were that the mean BLL in children was below the CDC level of concern and was similar to those observed in children from neighbouring countries, although $4.5 \%$ of children had BLL above $10 \mu \mathrm{g} /$ $\mathrm{dL}$, the level at which CDC guidelines recommend public health action be initiated. BLL were higher in children living in refugee camps near industrial regions with high traffic and significantly higher in children from larger families and families with smaller household area.

\section{References}

1. Brown LM et al. Blood lead levels and risk factors for lead poisoning in children and caregivers in Chuuk State, Micronesia. International Journal of Hygiene and Environmental Health, 2005, 208:231-236.

2. Singh AK, Singh $M$. Lead decline in the Indian environment resulting from the petrol-lead phase-out programme. Science of the Total Environment, 2006, 368:686-694.

3. Hershko $\mathrm{C}$ et al. Lead poisoning by contaminated flour. Reviews on Environmental Health, 1989, 8:17-23.

4. El Sharif $\mathrm{N}$ et al. Re-emergence of lead poisoning from contaminated flour in a West Bank Palestinian village. International Journal of Occupational and Environmental Health, 2000, 75:183-186.

5. Bellinger DC, Stiles KM, Needleman HL. Low-level lead exposure, intelligence and academic achievement: a long-term follow-up study. Pediatrics, 1992, 90:855-861.

6. Ahamed M et al. Environmental exposure to lead and its correlation with biochemical indices in children. Science of the Total Environment, 2005, 346:48-55.

7. Fadrowski JJ et al. Blood lead level and kidney function in US adolescents: The Third National Health and Nutrition Examination Survey. Archives of Internal Medicine, 2010, 170:75-82.

8. Vahter M et al. Metals and women's health. Environmental Research, 2002, 88:145-155.

9. Jusko TA et al. Blood lead concentrations $<10$ microg/dL and child intelligence at 6 years of age. Environmental Health Perspectives, 2008, 116:243-248.

10. Lanphear BP et al. Low-level environmental lead exposure and children's intellectual function: an international pooled analysis. Environmental Health Perspectives, 2005, 113:894-899.

11. Centers for Disease Control and Prevention. Advisory committee on childhood lead poisoning prevention Interpreting and managing blood lead levels $<10$ microg/dL in children and reducing childhood exposures to lead: recommendations of CDC's Advisory Committee on Childhood Lead Poisoning Prevention. Mortality Morbidity Weekly Report, 2007, 56(RR8):1-16.

12. Palestinian Central Bureau of Statistics. Palestinian National Authority [online database] (http://www.pcbs.gov.ps/DesktopDefault.aspx?lang=en, accessed 20 November 2012).
13. Järup L. Hazards of heavy metal contamination. British Medical Bulletin, 2003, 68:167-182.

14. Iqbal $S$ et al. Estimated burden of blood lead levels 5 microg/dl in 1999-2002 and declines from 1988 to 1994. Environmental Research, 2008, 107:305-311.

15. Pirkle JL et al. Exposure of the U.S. population to lead, 19911994. Environmental Health Perspectives, 1998, 106:745-750.

16. Centers for Disease Control and Prevention (CDC). Mortality Morbidity Weekly Report Blood lead levels in young children and selected sites, 1996-1999. Mortality Morbidity Weekly Report, 2000, 49:1133-1137.

17. Safi J et al. Childhood lead exposure in the palestinian authority, Israel, and Jordan: results from the Middle Eastern regional cooperation project, 1996-2000. Environmental Health Perspectives, 2006, 114:917-922.

18. Rubin $\mathrm{CH}$ et al. Childhood lead poisoning in Russia: a sitespecific pediatric blood lead evaluation. International Journal of Occupational and Environmental Health, 1997, 3:241-248.

19. Brody DJ et al. Blood lead levels in the US population. Phase 1 of the Third National Health and Nutrition Examination Survey (NHANES III, 1988 to 1991). Journal of the American Medical Association, 1994, 272:277-283.

20. Baghurst PA et al. Determinants of blood lead concentrations to age 5 years in a birth cohort study of children living in the lead smelting city of Port Pirie and surrounding areas. Archives of Environmental Health, 1992, 47:203-210.

21. Sharaf NE et al. Evaluation of children's blood lead level in Cairo, Egypt. American-Eurasian Journal of Agricultural and Environmental Sciences, 2008, 3:414-419.

22. Kaiser $\mathrm{R}$ et al. Blood lead levels of primary school children in Dhaka, Bangladesh. Environmental Health Perspectives, 2001, 109:563-566

23. Lovei M. Eliminating a silent threat: World Bank support for the global phase out of lead from gasoline. In: George AM, ed. Lead poisoning prevention and treatment: implementing $a$ national program in developing countries. Bangalore, India, The George Foundation, 1999:169-180.

24. Tong S, von Schirnding YE, Prapamontol T. Environmental lead exposure: a public health problem of global dimensions. Bulletin of the World Health Organization, 2000, 78:1068-1077. 